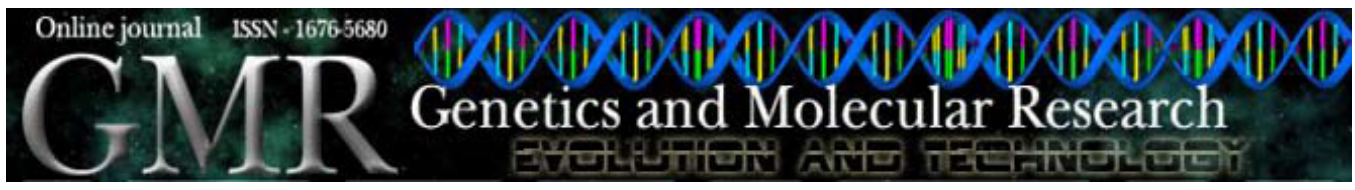

\title{
Gene silencing during development of in vitro-produced female bovine embryos
}

\author{
G.K.F. Merighe ${ }^{1}$, F.H. Biase ${ }^{1}$, W.K.F. Santos-Biase ${ }^{1}$, M.S. Miranda ${ }^{1}$, \\ T.H.C. de Bem ${ }^{1}$, Y.F. Watanabe ${ }^{2}$ and F.V. Meirelles ${ }^{1}$ \\ ${ }^{1}$ Departamento de Ciências Básicas, \\ Faculdade de Zootecnia e Engenharia de Alimentos, \\ Universidade de São Paulo, Pirassununga, SP, Brasil \\ ${ }^{2}$ Vitrogen-Pesquisa e Desenvolvimento em Biotecnologia da Reprodução \\ S/C Ltda., Cravinhos, SP, Brasil
}

Corresponding author: G.K.F. Merighe

E-mail: gkrempel@usp.br

Genet. Mol. Res. 8 (3): 1116-1127 (2009)

Received May 18, 2009

Accepted July 16, 2009

Published September 15, 2009

\begin{abstract}
In early development, female embryos (XX) produce twice the transcripts of $\mathrm{X}$-linked genes compared with male embryos (XY). During the course of development, inactivation of the $\mathrm{X}$ chromosome equilibrates gene dosage, making the development of female embryos viable. Moreover, the biotechnologies used for producing embryos in vitro seem to work better with male embryos, making it easier for them to reach the blastocyst stage and allow for complete gestation. We investigated the expression of three X-linked genes that are involved in development, XIST, G6PD, and HPRT, and of the transcript interferon- $\tau$, in male and female bovine blastocysts produced by nuclear transfer (NT) and by in vitro fertilization (IVF). Oocytes that had been matured in vitro were enucleated and reconstructed with somatic cells from adult animals at $18 \mathrm{~h}$ post-maturation. After fusion (two pulses of $2.25 \mathrm{kv} / \mathrm{cm}$ ) and chemical activation (5.0 $\mu \mathrm{M}$ ionomycin for $5 \mathrm{~min}$ and $2.0 \mathrm{mM}$ 6-DMAP for $3 \mathrm{~h}$ ), the oocytesomatic cell units were cultivated in $\mathrm{CR} 2$ with a monolayer of granulosa cells at $38.8^{\circ} \mathrm{C}$, in a humidified $5 \% \mathrm{CO}_{2}$ atmosphere. IVF embryos were inseminated, after centrifugation in a Percoll gradient, with $2 \times 10^{6}$ sperm/ $\mathrm{mL}$ TALP medium supplemented with BSA and PHE and cultivated under the same conditions as the cloned embryos. We used real-time PCR to
\end{abstract}


analyze the gene expression of individual blastocysts compared to expression of the housekeeping gene, GAPDH. The gene XIST was expressed in female embryos and not in male embryos produced by IVF, though it was expressed at low levels in male embryos produced by NT. Unlike previous reports, we found lower levels of the transcript of G6PD in females than in males, suggesting double silencing or other mechanisms of control of this gene. Female embryos produced by IVF expressed the HPRT gene at a higher level than female embryos produced by NT, suggesting that gene silencing proceeds faster in NT-produced female embryos due to "inactivation memory" from the nucleus donor. In conclusion, male and female embryos express different levels of X-chromosome genes and failures of these genes that are essential for development could reduce the viability of females. Nuclear transfer can modify this relation, possibly due to epigenetic memory, leading to frequent failures in nuclear reprogramming.

Key words: X-chromosome inactivation; Nuclear reprogramming; Bovine embryos; Nuclear transfer and sex

\section{INTRODUCTION}

In vitro culture has for decades proved its ability to allow full development in oocytes collected from non-ovulated follicles with reasonable rates (Avery et al., 1989, 1991; Carvalho et al., 1996; Gutiérrez-Adán et al., 2001). However, besides an effect of oocyte competence, the inherited spermatozoid sex chromosome may interfere in the probability of an embryo to result in a term gestation. These effects are driven by an interaction of the environment (culture conditions) with the genotypes, with influence on embryonic, fetal and placental development in cattle, resulting in a higher incidence of male newborns (Rieger, 1992; Bavister, 1995; Niemann and Wrenzycki, 2000; Kochhar et al., 2001).

Under adverse culture conditions, a high proportion of females reach the morula stage, but they fail to advance to the blastocyst stage (Gutiérrez-Adán et al., 2000; Wrenzycki et al., 2002). Previous studies showed that females have two active $X$ chromosomes up to the expanded blastocyst stage, leading to extra X chromosome gene transcripts and to additional susceptibility to unbalanced metabolism.

The main factor responsible for the inactivation of the X chromosome is the XIST (X inactive specific transcript) gene, which transcribes a non-coding RNA that propagates from the location of its transcription throughout the length of the inactive $\mathrm{X}$ chromosome, remaining associated with it, blocking the transcription of its genes (Farazmand et al., 2001). Genes such as glycose6-phosphate dehydrogenase (G6PD) and hypoxanthine phosphoribosyltransferase (HPRT), which are important for metabolism, are located on the X chromosome, and both are subjected to inactivation. Their expression is involved in the control of free radicals. Embryo survival is directly related to their capacity to maintain cellular homeostasis in the cellular environment. G6PD, in its role of detoxifying reactive oxygen species, is responsible for maintaining cellular equilibrium (Rieger, 1992; Iwata et al., 1998; Nicol et al., 2000).

The lower levels of oxygen radicals in females, due to the double dose of G6PD, could be responsible for retarding development. On the other hand, males, with appropriate levels of oxygen 
radicals, could form blastocysts faster than females. These effects would explain why embryos produced in vitro stray significantly from a 1:1 sex ratio (Nicol et al., 2000; Iwata et al., 2002).

The identification of modifications of X-related gene expression in the embryo can provide us with a means to better understand the effect of in vitro culture on the development of male and female embryos. Our objective was to evaluate the expression of genes involved in the process of inactivation of the $\mathrm{X}$ chromosome in embryos, together with interferon- $\tau$ (IFN- $\tau$ ), a gene characterized as having a higher expression in female embryos but located in an autosomal chromosome (Larson and Kubisch, 1999; Kubisch et al., 2003), during the blastocyst stage of in vitro fertilization (IVF) and cloned embryos.

\section{MATERIAL AND METHODS}

\section{Chemicals}

Chemicals and media were purchased from Sigma Chemical Co., St. Louis, MO, USA, unless otherwise stated.

\section{In vitro maturation}

To obtain oocytes for in vitro maturation, bovine ovaries were collected from zebu and crossbreed cows in a slaughterhouse and transported to the laboratory in $0.9 \%$ saline solution at $35^{\circ} \mathrm{C}$. Oocytes were immediately aspirated from 2 to $8 \mathrm{~mm}$ follicles using an 18-gauge needle attached to a $10-\mathrm{mL}$ syringe, and only oocytes with a multilayered, compact cumulus, and dark evenly granulated cytoplasm were selected. The oocytes were subsequently matured in TCM199 with Earle's salts, L-glutamine and $2.2 \mathrm{~g} / \mathrm{L}$ sodium bicarbonate (Gibco Lab., Grand Island, NY, USA), supplemented with $10 \%$ fetal bovine serum (FBS), $22 \mu \mathrm{g} / \mathrm{mL}$ sodium pyruvate, $50 \mu \mathrm{g} / \mathrm{mL}$ gentamicin, $0.5 \mu \mathrm{g} / \mathrm{mL}$ FSH (Folltropin ${ }^{\mathrm{TM}}$ ), $50 \mu \mathrm{g} / \mathrm{mL}$ hCG (Vetecor ${ }^{\mathrm{TM}}$ ) and $1 \mu \mathrm{g} / \mathrm{mL}$ estradiol in $100-\mu \mathrm{L}$ microdroplets of maturation medium, and were covered with mineral oil. Groups of 25-30 oocytes were matured under a humidified atmosphere of $5 \% \mathrm{CO}_{2}$ in air at $38.8^{\circ} \mathrm{C}$ for $18 \mathrm{~h}$.

\section{In vitro fertilization}

After the maturation period, the oocytes were fertilized in vitro in $100-\mu \mathrm{L}$ microdroplets of TALP-IVF medium supplemented with $10 \mu \mathrm{g} / \mathrm{mL}$ heparin, $22 \mu \mathrm{g} / \mathrm{mL}$ sodium pyruvate, 50 $\mu \mathrm{g} / \mathrm{mL}$ gentamicin, $6 \mathrm{mg} / \mathrm{mL}$ fatty acid-free BSA and PHE solution $(20 \mu \mathrm{M}$ penicillamine, 10 $\mu \mathrm{M}$ hypotaurine and $2.0 \mu \mathrm{M}$ epinephrine). Frozen-thawed semen, derived from a single Nelore bull and tested for use in IVF, was centrifuged using a discontinuous density Percoll gradient (45 and 90\%) to select viable spermatozoa. The sperm concentration was then adjusted to a final concentration of $2 \times 10^{5}$ motile sperm $/ \mathrm{mL}$ in each fertilization drop $(10 \mu \mathrm{L}$ sperm solution of $2 \mathrm{x}$ $10^{6}$ per a $100-\mu \mathrm{L}$ drop). After $18 \mathrm{~h}$ of co-culture with spermatozoa at $38.8^{\circ} \mathrm{C}, 5 \% \mathrm{CO}_{2}$ in air and maximum humidity, the oocytes were washed and transferred to the culture medium.

\section{In vitro culture}

After the in vitro maturation and IVF process, the cumulus cells were removed and the 
presumptive zygotes were cultured in modified CR2 medium supplemented with $10 \% \mathrm{FBS}$, co-cultivated with granulosa cells (Watanabe et al., 1999), at $38.8^{\circ} \mathrm{C}$ in a humidified atmosphere of $5 \% \mathrm{CO}_{2}$ in air. On day 9 (fertilization = day 0 ), the blastocysts were removed from culture and stored individually for later gene expression analysis.

\section{Nuclear transfer}

To produce embryos by nuclear transfer, mature oocytes were placed in PBS supplemented with $4 \mathrm{mg} / \mathrm{mL}$ BSA and $2 \mathrm{mg} / \mathrm{mL}$ hyaluronidase to remove the cumulus cells by gentle pipetting, and then selected based on the presence of the first polar body. Subsequently, they were maintained in CR2 medium with $10 \mu \mathrm{g} / \mathrm{mL}$ cytochalasin B and $10 \mu \mathrm{g} / \mathrm{mL}$ Hoechst 33342 stain for $20 \mathrm{~min}$. The oocytes were enucleated in PBS supplemented with 10\% FBS and $10 \mu \mathrm{g} /$ $\mathrm{mL}$ cytochalasin $\mathrm{B}$, by removing a small portion of the cytoplasm near the region of the first polar body. The aspirated portion was exposed to ultraviolet irradiation to confirm enucleation. The oocytes were later reconstructed with somatic cells from an adult animal at stage G1/G0 of the cell cycle, inserting the cell into the perivitelline space.

\section{Electrofusion and chemical activation}

The oocyte-somatic cell complexes were placed in a fusion chamber and fused by two DC pulses of $2.25 \mathrm{kV} / \mathrm{cm}$ for $65 \mu \mathrm{s}$ in $0.3 \mathrm{M}$ mannitol containing $0.1 \mathrm{mM} \mathrm{MgSO}{ }_{4}, 0.5 \mathrm{mM}$ HEPES and $0.05 \% \mathrm{BSA}, \mathrm{pH} 7.04$. Following fusion, the oocytes were placed in culture medium for $1 \mathrm{~h}$ before activation. Reconstructed oocytes were chemically activated by exposure to $5 \mu \mathrm{M}$ ionomycin for $5 \mathrm{~min}$ in HEPES-buffered TCM-199 supplemented with $1 \mathrm{mg} / \mathrm{mL}$ BSA, and placed in culture medium containing $2.0 \mathrm{mM}$ 6-dimethylaminopurine for $3 \mathrm{~h}$ at $38.8^{\circ} \mathrm{C}$ in a humidified atmosphere of $5 \% \mathrm{CO}_{2}$ in air.

After activation, the oocytes were cultivated in CR2 medium supplemented with $10 \%$ FBS in co-cultivation with granulosa cells at $38.8^{\circ} \mathrm{C}$ in a humidified atmosphere of $5 \% \mathrm{CO}_{2}$ in air, for nine days, when they were removed from the culture system and stored individually for later analysis of gene expression.

\section{Establishment of nuclear donor cell cultures}

The somatic cell line used as nucleus donor was derived from a skin biopsy obtained from adult male and female Nelore animals. The biopsy was immediately transported to the laboratory in PBS on ice, the tissue was cut into small pieces (approximately $2 \mathrm{~mm}$ ), washed in PBS and then transferred to a 35-mm diameter Petri dish. The culture was done in Dulbecco's modified Eagle's medium (DMEM; Gibco) supplemented with 20\% FBS, $22 \mu \mathrm{g} / \mathrm{mL}$ sodium pyruvate, $1 \mathrm{mM}$ glutamine and $50 \mu \mathrm{g} / \mathrm{mL}$ gentamicin, incubated at $38.8^{\circ} \mathrm{C}$ in a $5 \% \mathrm{CO}_{2}$ in air, with renewal of the medium every three days.

After the first cells began to grow, the medium was substituted with DMEM supplemented with $10 \%$ FBS and the culture continued until the third passage, at which point the cells were ready for the nuclear transfer procedure. Five days after the initiation of the culture, the culture medium was substituted by DMEM supplemented with $0.5 \%$ FBS (serum starvation), in order to increase the number of cells at the G1/G0 stage. 


\section{Storage and sexing of the embryos}

The embryos of the hatched blastocyst stage were stored individually in PBS supplemented with $0.1 \%$ polyvinylpyrrolidone and $1 \mathrm{unit} / \mu \mathrm{L}$ RNase inhibitor. They were immediately immersed in liquid nitrogen and stored at $-80^{\circ} \mathrm{C}$ for later analysis of gene expression.

The embryos produced by IVF were sexed using polymerase chain reaction (PCR). The DNA fragments were amplified beginning at the equivalent of $1 / 3$ of a blastocyst. PCR was run in a final volume of $25 \mu \mathrm{L}$ containing $1 \mathrm{X}$ PCR buffer $(20 \mathrm{mM}$ Tris- $\mathrm{HCl}, \mathrm{pH} 8.0,50$ $\mathrm{mM} \mathrm{KCl}), 1.5 \mathrm{mM} \mathrm{MgCl}_{2}, 200 \mu \mathrm{M}$ of each dNTP, $0.5 \mu \mathrm{M}$ Y-specific oligonucleotide initiator (forward: 5'CCTCCCCTTGTTCAAACGCCCGGAATCATT3' and reverse: 5'TGCTTGACT GCAGGGACCGAGAGGTTTGGG3'), $0.08 \mu \mathrm{M}$ X-specific oligonucleotide initiator (forward 5'AGGTCGCGAGATTGGTCGCTAGGTCATGCA3' and reverse: 5'AAGACCTCGAGAG ACCCTCTTCAACACGT3'; Wrenzycki et al., 2002) and 1 unit Taq DNA polymerase (Invitrogen, Carlsbad, CA, USA). PCR consisted of an initial step at $97^{\circ} \mathrm{C}$ for $2 \mathrm{~min}$, followed by 32 cycles of $30 \mathrm{~s}$ at $95^{\circ} \mathrm{C}, 30 \mathrm{~s}$ at $60^{\circ} \mathrm{C}$, and $45 \mathrm{~s}$ at $72^{\circ} \mathrm{C}$. The final extension step was run at $72^{\circ} \mathrm{C}$ for $5 \mathrm{~min}$. The amplification product, which resulted in a 300 -bp fragment for females and two fragments of 300 and $210 \mathrm{bp}$ for males, was run by electrophoresis on $1.5 \%$ agarose gel with $1 \mathrm{X}$ TBE buffer ( $89 \mathrm{mM}$ Tris, $89 \mathrm{mM}$ boric acid and $2 \mathrm{mM}$ EDTA, pH 8.0), containing $0.5 \mu \mathrm{g} / \mathrm{mL}$ ethidium bromide. The image was visualized with an FLA 3000G Scanner (FUJIFILM) at $520 \mathrm{~nm}$ excitation and $580 \mathrm{~nm}$ emission wavelengths.

\section{Amplification of RNA}

RNA of a single embryo at the hatched blastocyst stage was amplified with a Superscript $^{\mathrm{TM}}$ RNA Amplification System kit (Invitrogen). In brief, the protocol was initiated with the synthesis of the first strand of cDNA, adding to the tube containing the RNA, oligo(dT)-T7 and RNase-free water. The reaction was incubated at $70^{\circ} \mathrm{C}$ for $10 \mathrm{~min}$, and the following were then added: buffer for synthesis of the first strand, DTT, dNTP, RNase inhibitor, and reverse transcriptase enzyme Superscript III. The reaction was incubated at $46^{\circ} \mathrm{C}$ for $2 \mathrm{~h}$, followed by $10 \mathrm{~min}$ at $70^{\circ} \mathrm{C}$, to inactivate the enzyme. The second strand was synthesized right after the first strand was produced, adding to the reaction tube the buffer for the second strand, dNTP, and the enzymes DNA polymerase I, DNA ligase and RNase II. This incubation was run at $16^{\circ} \mathrm{C}$ for $2 \mathrm{~h}$.

The double-stranded cDNA was purified soon after termination of synthesis, adding loading buffer to the reaction tube and, after homogenization, transferring it to the purification column and centrifuging at $12,000 \mathrm{~g}$. Washing buffer was then added to the column and it was centrifuged again at $12,000 \mathrm{~g}$. The last step included addition of RNase-free water and centrifugation at $12,000 \mathrm{~g}$ to recover the cDNA. cDNA was separated by precipitation with absolute ethanol, $3 \mathrm{M}$ sodium acetate and glycogen.

RNA was amplified in vitro from the double-stranded cDNA. The reaction was carried out using the enzyme T7 RNA polymerase, T7 reaction buffer (Invitrogen) and $3.75 \mathrm{mM}$ dNTP (ATP, CTP, GTP, and UTP), incubating the reaction mixture at $37^{\circ} \mathrm{C}$ for $16 \mathrm{~h}$. After the reaction was terminated, the amplified RNA was exposed to DNase I for $30 \mathrm{~min}$ at $37^{\circ} \mathrm{C}$.

The amplified RNA was purified, adding binding buffer (Invitrogen) and absolute ethanol to the reaction tube, and after homogenization the mixture was added to a purification column and centrifuged at 12,000 $\mathrm{g}$. Washing buffer (Invitrogen) was then added to 
the column, and it was centrifuged again at $12,000 \mathrm{~g}$. The last step included the addition of RNase-free water and centrifugation at $12,000 \mathrm{~g}$ to recover the RNA.

\section{Reverse transcription}

Reverse transcription of the amplified RNA was run with the Improm II kit (Promega, Madison, WI, USA). Briefly, the protocol began with incubation of the RNA with $0.5 \mu \mathrm{g}$ of the oligonucleotide polyA $\mathrm{A}_{12}$ for $5 \mathrm{~min}$ at $70^{\circ} \mathrm{C}$. Next, buffer $1 \mathrm{X}(250 \mathrm{mM}$ Tris, $375 \mathrm{mM} \mathrm{KCl}$ and $50 \mathrm{mM}$ DTT), $3 \mathrm{mM} \mathrm{MgCl}, 0.5 \mathrm{mM}$ dNTP, 40 units RNase inhibitor (Amersham Biosciences, Piscataway, NJ, USA) and $1.0 \mu \mathrm{L}$ reverse transcriptase enzyme Improm were added to the reaction tube, in a final volume of $20 \mu \mathrm{L}$. The reaction was incubated at $42^{\circ} \mathrm{C}$ for $60 \mathrm{~min}$, followed by $15 \mathrm{~min}$ at $70^{\circ} \mathrm{C}$, and then cooled to $4^{\circ} \mathrm{C}$.

\section{Amplification of the cDNA of the target genes}

cDNA samples from hatched blastocysts that had been produced by IVF and by nuclear transfer were analyzed with real-time PCR thermocycler (Applied Biosystems 7500 Real Time PCR System, Applied Biosystems, Foster City, CA, USA). The PCR products of the genes glyceraldehyde 3-phosphate dehydrogenase (GADPH), XIST, G6PD, IFN- $\tau$, and HPRT were detected with the TaqMan ${ }^{\circledR}$ System (Applied Biosystems). The reactions were carried out in quadruplicate, in a final volume of $20 \mu \mathrm{L}$, containing 1X PCR mix TaqMan ${ }^{\circledR}, 0.9 \mu \mathrm{M}$ of each initiator oligonucleotide, $0.25 \mu \mathrm{M}$ of each probe and $1 \%$ of the embryo. PCR was initiated with activation of uracil-Nglycosylase at $50^{\circ} \mathrm{C}$ for $2 \mathrm{~min}$, followed by $10 \mathrm{~min}$ at $95^{\circ} \mathrm{C}$ for activation of DNA polymerase, 57 amplification cycles of $15 \mathrm{~s}$ at $95^{\circ} \mathrm{C}$ and $1 \mathrm{~min}$ at $60^{\circ} \mathrm{C}$ to anneal and extend the initiator oligonucleotides. The primer sequences, as well as the size of the PCR fragments, are described in Table 1.

Table 1. Sequences of the primer oligonucleotides (GAPDH, XIST, IFN- $\tau$, G6PD, and HPRT), the size of the polymerase chain reaction fragments and GenBank code used for gene expression analysis.

\begin{tabular}{|c|c|c|c|}
\hline Gene & Sequence of the primer oligonucleotide and probe $\left(5^{\prime} \rightarrow 3^{\prime}\right)$ & Fragment (bp) & GenBank code \\
\hline GAPDH & & $76 \mathrm{bp}$ & NM_001034034 \\
\hline Forward & AAGGCCATCACCATCTTCCA & & \\
\hline Reverse & CCACTACATACTCAGCACCAGCAT & & \\
\hline Probe & AGCGAGATCCTGCCAACATCAAGTGG & & \\
\hline XIST & & $99 \mathrm{bp}$ & NR_001464 \\
\hline Forward & TTGGCTTTTAGATTAATTTGATGAACAGCAT & & \\
\hline Reverse & CCCTTTAGACTAGGCCCATTTCATA & & \\
\hline Probe & ATTCTAGGTCCTGAGCATAAG & & \\
\hline IFN- $\tau$ & & $74 \mathrm{bp}$ & AF238612 \\
\hline Forward & CCTTCGTGCTCTCTCTACTGATG & & \\
\hline Reverse & CAGGTAACAACCCAGAGATCGT & & \\
\hline Probe & CCGTAGCTGACCAGCACC & & \\
\hline G6PD & & $58 \mathrm{bp}$ & XM_583628 \\
\hline Forward & GCCGTCCTCTATGTGGAAAATGA & & \\
\hline Reverse & CGCAGCGCAGGATGAAG & & \\
\hline Probe & CACCCCGTCCCAGCGC & & \\
\hline HPRT & & $92 \mathrm{bp}$ & NM_001034035 \\
\hline Forward & GTTGTGGGATATGCCCTTGACTAT & & \\
\hline Reverse & GCTTTGTATTTTGCTTTTCCAGTTTCG & & \\
\hline Probe & CACACACGTGATTCAAG & & \\
\hline
\end{tabular}




\section{Statistical analysis}

The efficiency of the reactions was estimated using linear regression of the log of the fluorescence intensity at each cycle, using the LinRegPCR program (Ramakers et al., 2003). The relative differences between the groups (female and male nuclear transfer, female and male IVF) for each gene, XIST, G6PD, HPRT, and IFN- $\tau$, were estimated using GAPDH as a reference gene (Pfaffl, 2001). Differences between the expression levels were analyzed using the REST program; comparisons were made between samples and the control (Pfaffl et al., 2002).

\section{RESULTS AND DISCUSSION}

We investigated the expression of four genes in bovine embryos in the hatched blastocyst stage that had been produced by nuclear transfer and IVF, three of which are X-linked, XIST, G6PD and HPRT, and a fourth gene influenced by X-chromosome inactivation, IFN- $\tau$, normalized with the expression of the constitutive gene GAPDH.

In vitro embryo manipulation and culture are known to cause abnormalities in the expression of genes that are important for development, affected by in vitro culture conditions, including culture media, protein supplements and the nuclear transfer protocol (Wrenzycki et al., 1999).

The transcript of XIST is responsible for the $\mathrm{X}$ inactivation signal during the blastocyst stage (De La Fuente et al., 1999), but although XIST expression is detected during this stage, the X-linked transcript gender variation can be detected until inactivation is complete. As expected, we found higher expression of the XIST gene in female embryos produced both by nuclear transfer and by IVF compared with male embryos. The male embryos produced by IVF did not express this gene; however, as in our study we applied individual analysis, we found XIST expression in one single male embryo produced by nuclear transfer at the hatched blastocyst stage $(\mathrm{P}<0.05$; Figure 1$)$.

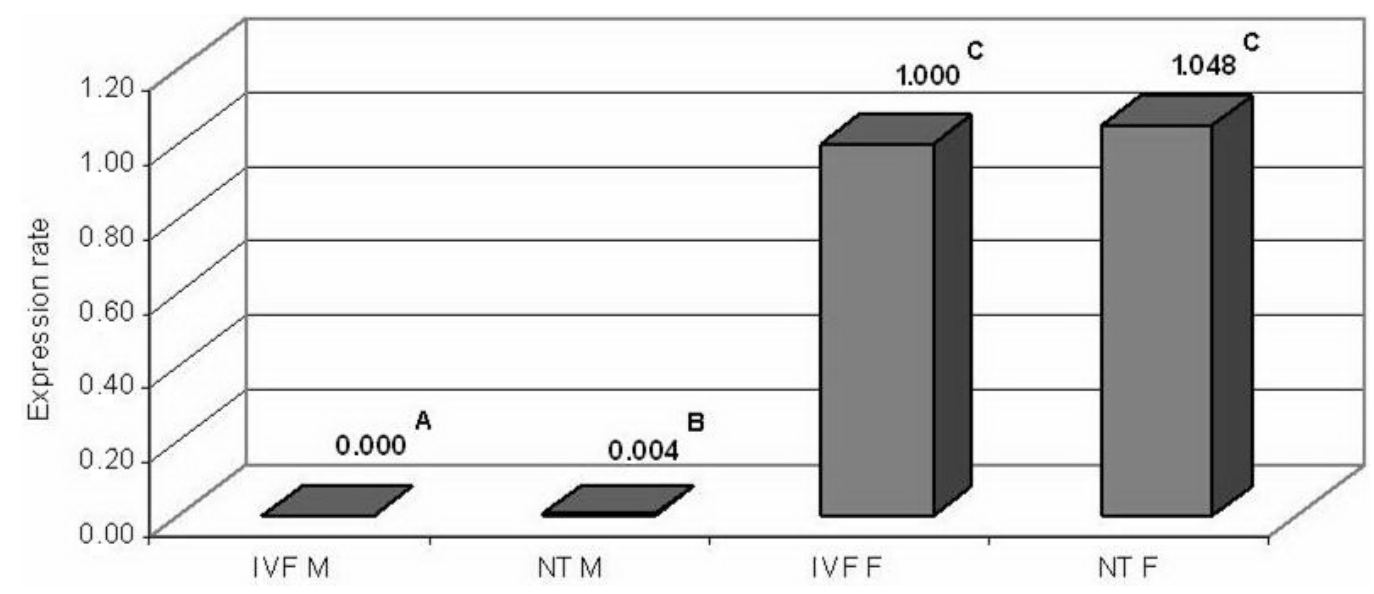

Figure 1. Relative expression of $X$ inactive specific transcript (XIST) gene transcript in male (M) and female (F) bovine blastocysts produced by nuclear transfer (NT) and by in vitro fertilization (IVF). Values followed by different letters indicate significant differences between groups $(\mathrm{P}<0.05)$. 
XIST RNA has also been detected in male human zygotes, embryos at the cleavage stage (Daniels et al., 1997), human at the blastocyst stage (Ray et al., 1997), and mouse at the blastocyst stage (Lee et al., 1999). Peippo et al. (2002) observed XIST gene transcripts in male bovine embryos, although a significantly higher expression was found in females at the same developmental stage. Because the XIST gene has been found in both male and female embryos, the authors suggested that some other mechanism is involved in X-chromosome inactivation, which together with the XIST transcript, has a role in the selection of the X chromosome that is inactivated (Daniels et al., 1997).

Expression of the XIST gene in female embryos equilibrates the unequal level of expression of X-linked genes. Consequently, the quantity of transcripts of the genes G6PD and HPRT should gradually be compensated between genders initiating after the XIST gene is detected in the embryos (Daniels et al., 1997).

However, failures in nuclear reprogramming of cloned embryos have been reported to affect the extent of gene silencing (Wilmut et al., 1997). Hence, expression of the XIST gene does not guarantee the normal expression levels of other X-linked genes, since the expression of these genes is controlled in other ways beside inactivation.

Unexpectedly, we found significantly lower expression of G6PD in females compared to males, both in embryos produced by nuclear transfer and those produced by IVF (Figure 2). This result contrasts with previously reported data (Daniels et al., 1997) and can be possibly related to the silencing of the G6PD gene in both X chromosomes at least in some of the cells of the female blastocysts.

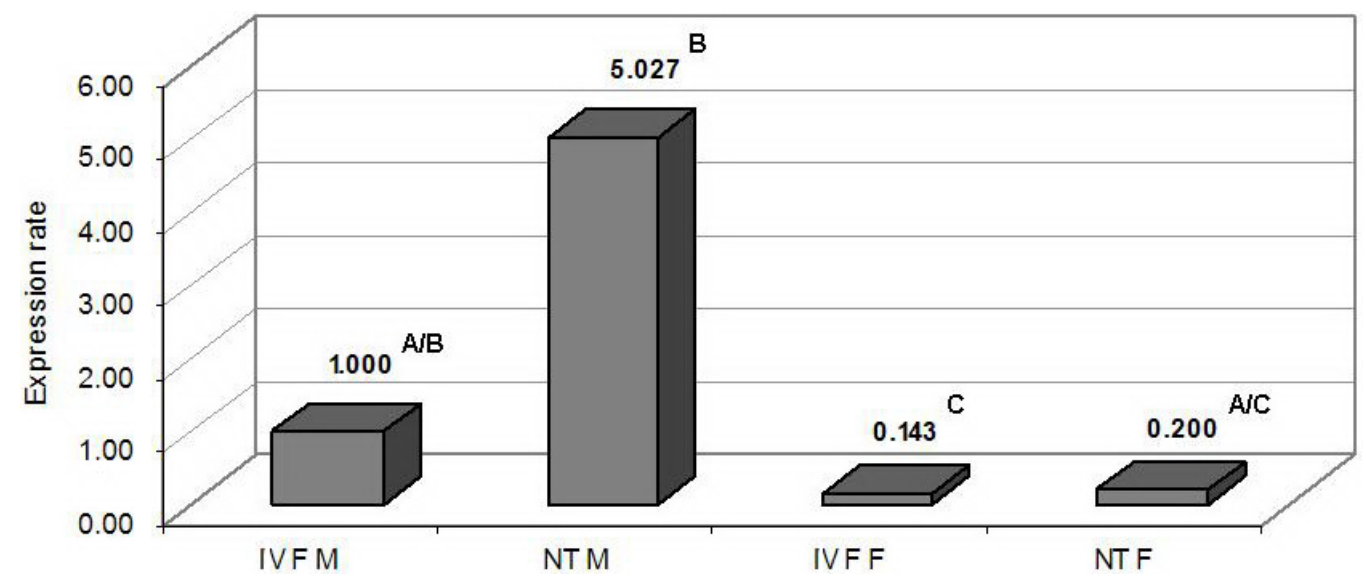

Figure 2. Relative expression of glycose-6-phosphate dehydrogenase (G6PD) gene transcript in male (M) and female (F) bovine blastocysts produced by nuclear transfer (NT) and by in vitro fertilization (IVF). Values followed by different letters indicate significant differences between groups $(\mathrm{P}<0.05)$.

Other authors also found dimorphic differences in the expression of some genes located on the $\mathrm{X}$ chromosome during the development of morulas and blastocysts produced in vitro (De La Fuente et al., 1999; Peippo et al., 2002). Evaluating XIST gene expression, together with G6PD and HPRT, the authors found that although HPRT showed a similar pattern of expression between genders after 2 to 3 days from first detection of XIST transcripts, the G6PD transcripts 
still showed higher levels in female embryos (Peippo et al., 2002). Together with data shown in this study, these articles suggest a complex control of $\mathrm{X}$ chromosome gene expression, which can be influenced by other mechanisms that regulate the $\mathrm{X}$ inactivation process.

Given the role of G6PD in the control of free radicals, embryos and fetuses that are deficient in this transcript are more vulnerable to oxidative stress (Rieger, 1992). This fact could therefore be the cause of lower rate of blastocysts in female embryos. On the other hand, the deficiency in the expression of G6PD in female embryos cannot be attributed solely to the XISTmediated inactivation of the X chromosome, given that the expression of XIST was detected in both female groups. We believe that this inactivation is influenced by the in vitro environment.

The expression of G6PD by embryos seems to control the production of IFN- $\tau$, being associated with greater throughput of the pentose-phosphate cycle, because various transcription factors are sensitive to the redox state of the cellular environment (Morel and Barouti, 1999; Wenger, 2000; Haddad, 2002). Therefore, the lower production of IFN- $\tau$ by males is a consequence of their greater sensitivity to oxidative stress (Gutiérrez-Adán et al., 2000; Iwata et al., 2002).

We observed that male and female bovine embryos did not differ in their expression of IFN- $\tau$ at the hatched blastocyst stage (Figure 3 ). The production of IFN- $\tau$ was not affected because the G6PD levels were not increased in female embryos. These results, also found by other investigators, demonstrate that the expression of G6PD gene influences the production of IFN- $\tau$ during early embryo development (Kimura et al., 2004a,b). On other hand, although we observed a decreased level in G6PD transcripts, we did not observe a correlation with decreased IFN- $\tau$ transcripts. This result indicates that further studies are necessary to determine the influence of $\mathrm{X}$-inactivation on IFN- $\tau$ transcription.

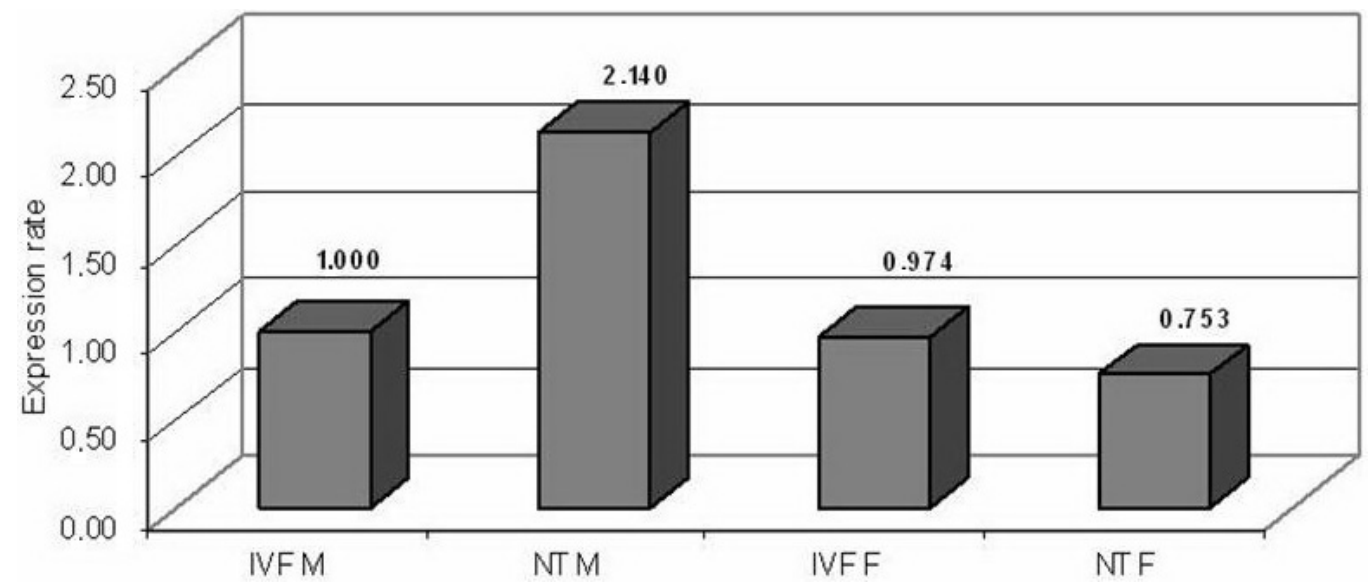

Figure 3. Relative expression of interferon- $\tau$ (IFN- $\tau$ ) gene transcript in male (M) and female $(\mathrm{F})$ bovine blastocysts produced by nuclear transfer (NT) and by in vitro fertilization (IVF). No significant differences were observed between groups $(\mathrm{P}>0.05)$.

In this study, we observed a similar expression of HPRT gene between genders. However, we report for the first time an interaction of gender and the method applied for the production of the embryos. That is, female embryos produced by IVF had higher levels of HPRT than those produced by nuclear transfer (Figure 4). 


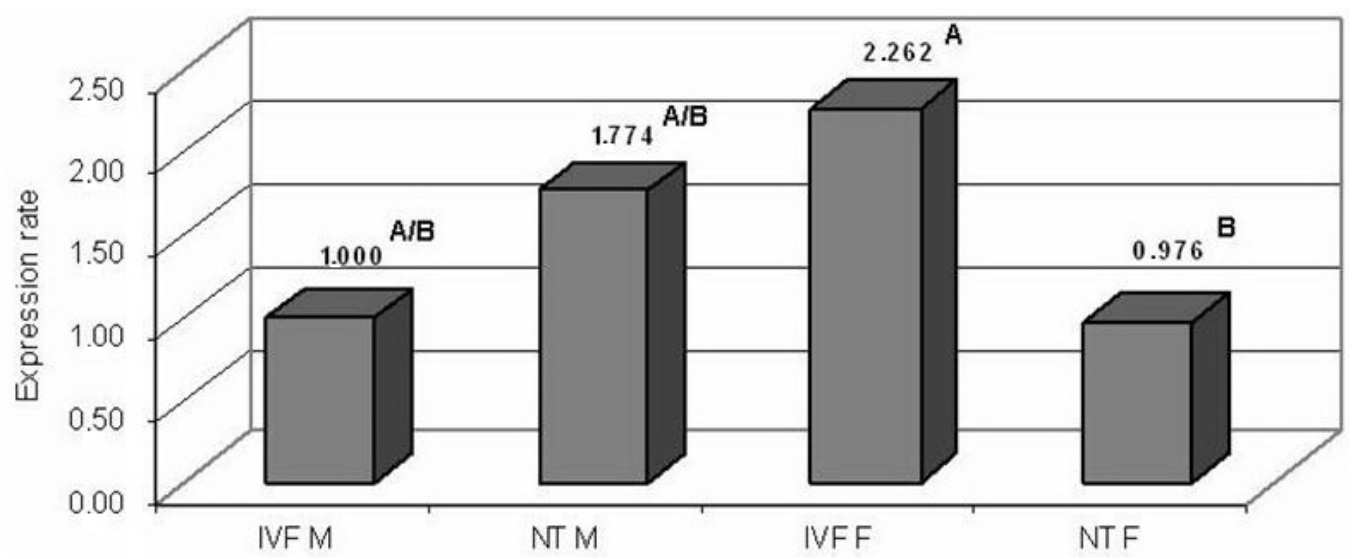

Figure 4. Relative expression of hypoxanthine phosphoribosyltransferase (HPRT) gene transcript in male (M) and female (F) bovine blastocysts produced by nuclear transfer (NT) and by in vitro fertilization (IVF). Values followed by different letters indicate significant differences between groups $(\mathrm{P}<0.05)$.

Peippo et al. (2002) also found similar levels of HPRT gene transcripts in males and females at the blastocyst stage. However, other authors observed significantly higher levels of these transcripts in females than in males at the same stage of development (Gutiérrez-Adán et al., 2000; Lonergan et al., 2000).

The literature shows that the period of inactivation of the X chromosome and the synthesis and accumulation of transcripts differ between embryos produced in vivo versus in vitro (Lucas-Hahn et al., 2001). In our study, we showed one more variation: the period of inactivation of the $\mathrm{X}$ chromosome may differ between biotechnologies (cloning vs IFV).

The different levels of HPRT between IVF and cloning female embryos indicate that the HPRT gene was not yet silenced in one of the X chromosomes at least in some of the cells in female embryos produced by IVF. On other hand, gene silencing proceeded faster in nuclear transfer-produced female embryos possibly due to an "inactivation memory" from the nucleus donor.

We conclude that male and female embryos at the hatched blastocyst stage produced in vitro express different levels of $\mathrm{X}$-chromosome genes, and that the failures of these essential genes for development could reduce the viability of females. Moreover, the X chromosome inactivation process in female embryos produced by nuclear transfer occurs by different kinetics, possibly due to epigenetic memory, leading to frequent failures in nuclear reprogramming.

\section{ACKNOWLEDGMENTS}

Research supported by FAPESP, CLONEST $^{\circledR}$ and FZEA/USP.

\section{REFERENCES}

Avery B, Bak A and Schmidt M (1989). Differential cleavage rates and sex determination in bovine embryos. Theriogenology 32: 139-147.

Avery B, Madison V and Greve T (1991). Sex and development in bovine in vitro fertilized embryos. Theriogenology 35: 953-963. 
Bavister BD (1995). Culture of preimplantation embryos: facts and artifacts. Hum. Reprod. Update 1: $91-148$.

Carvalho RV, Del Campo MR, Palasz AT, Plante Y, et al. (1996). Survival rates and sex ratio of bovine IVF embryos frozen at different developmental stages on day 7. Theriogenology 45: 489-498.

Daniels R, Zuccotti M, Kinis T, Serhal P, et al. (1997). XIST expression in human oocytes and preimplantation embryos. Am. J. Hum. Genet. 61: 33-39.

De La Fuente R, Hahnel A, Basrur PK and King WA (1999). X inactive-specific transcript (XIST) expression and X chromosome inactivation in the preattachment bovine embryo. Biol. Reprod. 60: 769-775.

Farazmand A, Koykul W, Peippo J, Baguma-Nibasheka M, et al. (2001). Sex-linked genes are not silenced in fetal bovine testes expressing X-inactive specific transcript (XIST). J. Exp. Zool. 290: 327-340.

Gutierrez-Adán A, Oter M, Martinez-Madrid B, Pintado B, et al. (2000). Differential expression of two genes located on the $\mathrm{X}$ chromosome between male and female in vitro-produced bovine embryos at the blastocyst stage. Mol. Reprod. Dev. 55: 146-151.

Gutierrez-Adán A, Granados J, Pintado B and De La Fuente J (2001). Influence of glucose on the sex ratio of bovine IVM/ IVF embryos cultured in vitro. Reprod. Fertil. Dev. 13: 361-365.

Haddad JJ (2002). Antioxidant and prooxidant mechanisms in the regulation of redox(y)-sensitive transcription factors. Cell Signal. 14: 879-897.

Iwata H, Akamatsu S, Minami N and Yamada M (1998). Effects of antioxidants on the development of bovine IVM/IVF embryos in various concentrations of glucose. Theriogenology 50: 365-375.

Iwata H, Kimura K, Hashimoto S, Ohta M, et al. (2002). Role of G6PD activity on sex ratio and developmental competence of bovine embryos under oxidative stress. J. Reprod. Dev. 48: 447-453.

Kimura K, Spate LD, Green MP, Murphy CN, et al. (2004a). Sexual dimorphism in interferon- $\tau$ production by in vivoderived bovine embryos. Mol. Reprod. Dev. 67: 193-199.

Kimura K, Spate LD, Green MP and Roberts RM (2004b). Effects of oxidative stress and inhibitors of the pentose phosphate pathway on sexually dimorphic production of IFN- $\tau$ by bovine blastocysts. Mol. Reprod. Dev. 68: 88-95.

Kochhar HP, Peippo J and King WA (2001). Sex related embryo development. Theriogenology 55: 3-14.

Kubisch HM, Rasmussen TA and Johnson KM (2003). Interferon- $\tau$ in bovine blastocysts following parthenogenetic activation of oocytes: pattern of secretion and polymorphism in expressed mRNA sequences. Mol. Reprod. Dev. 64: 79-85.

Larson MA and Kubisch HM (1999). The effects of group size on development and interferon- $\tau$ secretion by in vitro fertilized and cultured bovine blastocysts. Hum. Reprod. 14: 2075-2079.

Lee JT, Davidow LS and Warshawsky D (1999). Tsix, a gene antisense to Xist at the X-inactivation centre. Nat. Genet. 21: 400-404.

Lonergan P, Gutierrez-Adan A, Pintado B, Fair T, et al. (2000). Relationship between time of first cleavage and the expression of IGF-I growth factor, its receptor, and two housekeeping genes in bovine two-cell embryos and blastocysts produced in vitro. Mol. Reprod. Dev. 57: 146-152.

Lucas-Hahn A, Herrmann D, Lemme E, Korsawe K, et al. (2001). Sex-related expression of the two X chromosome specific transcripts (G6PD, PGK) and the X inactive-specific transcript (XIST) in bovine blastocysts. Theriogenology 55: 412.

Morel Y and Barouki R (1999). Repression of gene expression by oxidative stress. Biochem. J. 342 (Pt 3): $481-496$.

Nicol CJ, Zielenski J, Tsui LC and Wells PG (2000). An embryoprotective role for glucose-6-phosphate dehydrogenase in developmental oxidative stress and chemical teratogenesis. FASEB J. 14: 111-127.

Niemann H and Wrenzycki C (2000). Alterations of expression of developmentally important genes in preimplantation bovine embryos by in vitro culture conditions: implications for subsequent development. Theriogenology 53: 21-34.

Peippo J, Farazmand A, Kurkilahti M, Markkula M, et al. (2002). Sex-chromosome linked gene expression in in-vitro produced bovine embryos. Mol. Hum. Reprod. 8: 923-929.

Pfaffl MW (2001). A new mathematical model for relative quantification in real-time RT-PCR. Nucleic Acids Res. 29 : e45.

Pfaffl MW, Horgan GW and Dempfle L (2002). Relative expression software tool (REST) for group-wise comparison and statistical analysis of relative expression results in real-time PCR. Nucleic Acids Res. 30: e36.

Ramakers C, Ruijter JM, Deprez RH and Moorman AF (2003). Assumption-free analysis of quantitative real-time polymerase chain reaction (PCR) data. Neurosci. Lett. 339: 62-66.

Ray PF, Winston RM and Handyside AH (1997). XIST expression from the maternal X chromosome in human male preimplantation embryos at the blastocyst stage. Hum. Mol. Genet. 6: 1323-1327.

Rieger D (1992). Relationships between energy-metabolism and development of early mammalian embryos. Theriogenology 37: 75-93.

Watanabe YF, Watanabe MR, Galerani MAV, Vila RA, et al. (1999). The influence of B2 and modified CR2 on the in vitro production of bovine with cumulus and oviduct co-culture. Theriogenology 51: 259.

Wenger RH (2000). Mammalian oxygen sensing, signalling and gene regulation. J. Exp. Biol. 203: 1253-1263. 
Wilmut I, Schnieke AE, McWhir J, Kind AJ, et al. (1997). Viable offspring derived from fetal and adult mammalian cells. Nature 385: 810-813.

Wrenzycki C, Herrmann D, Carnwath JW and Niemann H (1999). Alterations in the relative abundance of gene transcripts in preimplantation bovine embryos cultured in medium supplemented with either serum or PVA. Mol. Reprod. Dev. 53: 8-18.

Wrenzycki C, Lucas-Hahn A, Herrmann D, Lemme E, et al. (2002). In vitro production and nuclear transfer affect dosage compensation of the X-linked gene transcripts G6PD, PGK, and Xist in preimplantation bovine embryos. Biol. Reprod. 66: 127-134. 